\title{
Pendampingan Industri Kreatif Sandal Wisata di Desa Kebonsari Kabupaten Tuban
}

\author{
Slamet Widodo, Fuad Hasan \\ Program Studi Agribisnis Fakultas Pertanian \\ Universitas Trunojoyo Madura \\ E-mail : slametwidodo@trunojoyo.ac.id \\ http://dx.doi.org/10.21107/pgd.v4i2.4932
}

\begin{abstract}
Abstrak
Program pendampingan dalam rangka pengabdian masyarakat ini dilaksanakan di Desa Kebonsari, Kecamatan Tuban, Kabupaten Tuban. Mitra kegiatan IbM ini adalah UMKM yang bergerak pada usaha pembuatan sandal spon atau dikenal juga dengan sandal wisata, yaitu UMKM "Bintang Lima" (Mitra 1) dan UMKM "Tasmania" (Mitra 2). Kedua mitra berada di wilayah desa yang sama dan termasuk dalam wilayah ibukota kabupaten sehingga dapat mudah dijangkau. Lokasi berjarak $100 \mathrm{~km}$ dari Kampus UTM dengan akses jalan negara yang terjangkau. Metode yang digunakan adalah melalui kegiatan penyuluhan dan pendampingan pengurusan ijin usaha dan pendaftaran merek. Perancangan alat yaitu cutting machine dan mesin press untuk efisiensi produksi. Sedangkan untuk meingkatkan penjualan dan strategi marketing dilakukan pengembangan laman e-commerce. Hasil kegiatan telah sesuai dengan target yang diinginkan. Aspek legalisasi usaha menjadi fokus utama, dikarenakan strategi pengembangan usaha ke depan mensyaratkan adanya perijinan yang terkait dengan usaha. Melalui program ini, telah dilakukan pendampingan dalam pengurusan ijin usaha sehingga kedua mitra telah memiliki SIUP dan TDP. Upaya peningkatan produksi dilakukan dengan merancang alat yang mampu meningkatkan efisiensi produksi. Pada awalnya dilakukan pemotongan secara manual, kini telah tersedia mesin pemotong yang semi otomatis. Demikian pula dengan mesin pres. Pembuatan desain etiket merek sekaligus upaya pendaftaran merek telah dilakukan. Pendaftaran merek dilakukan melalui Sentra HAKI UTM. Upaya peningkatan penjualan dilakukan dengan perancangan toko online melalui laman sandalwisata.com.
\end{abstract}

Kata Kunci : industri sandal, pendampingan, pengabdian masyarakat, Tuban

\section{PENDAHULUAN}

Industri kreatif merupakan kelompok industri yang bercirikan adanya proses curahan ide atau kekayaan intelektual (intellectual property) menjadi suatu produk dengan nilai ekonomi tinggi tinggi. Industri kreatif semakin menunjukkan perannya dalam perekonomian Indonesia. Sampai dengan tahun 2017, pertumbuhan industry kreatif mencapai 5,76 persen. Angka ini diatas pertumbuhan ekonomi Indonesia yang sebesar 5,74 persen. Sumbangsih ekonomi kreatif terhadap PDB Indonesia mencapai Rp 642 triliun atau sebesar 7 persen (BPS, 2013). Salah satu bentuk dari indutri kreatif adalah usaha kerajinan. UNESCO mendefinisikan kerajinan sebagai industri yang menghasilkan produk-produk, baik secara keseluruhan menggunakan tangan atau menggunakan peralatan biasa, peralatan mekanis juga mungkin digunakan sepanjang kontribusi para pengrajin tetap lebih substansial pada komponen produk akhir.
Program pengabdian masyarakat melalui skema IbM ini dilaksanakan di Desa Kebonsari, Kecamatan Tuban, Kabupaten Tuban. Kedua mitra berada di wilayah desa yang sama dan termasuk dalam wilayah ibukota kabupaten sehingga dapat mudah dijangkau. Lokasi berjarak $100 \mathrm{~km}$ dari Kampus UTM dengan akses jalan negara yang terjangkau. Di Kabupaten Tuban terdapat usaha mikro yang bergerak di sektor industri kreatif, khususnya kerajinan. Salah satu jenis usaha kerajinan adalah pembuatan sandal busa/spon. Sandal busa/spon ini dikenal juga dengan nama sandal wisata karena seringkali dijual di tempat-tempat wisata dengan menampilkan desain baik gambar maupun tulisan yang menunjukkan icon wisata. Pada perkembangannya, sandal wisata tidak saja mengangkat tema desain icon wisata, namun juga menyesuaikan dengan segmen pasar yang dituju.

Jumlah Usaha Mikro Kecil Menengah (UMKM) di Kabupaten Tuban sampai tahun 
2015 sebanyak 16.223 usaha. Sekitar 500 UMKM sudah mengantongi ijin, sisanya 15.723 UMKM belum berijin. Kedua mitra dalam program ini termasuk UMKM yang belum mempunyai ijin usaha. Kedua mitra ini adalah UMKM "Bintang Lima" (Mitra 1) dan UMKM "Tasmania" (Mitra 2).

\section{METODE}

Program pengabdian masyarakat melalui skema IbM ini dilaksanakan selama 8 bulan. Adapun tahap pelaksanaan adalah sebagai berikut :

1. Penyuluhan : Penyuluhan diberikan kepada 30 pelaku UMKM yang berada di sekitar Mitra 1 dan Mitra 2. Penyuluhan ini memberikan materi mengenai aspek legalitas usaha dan HKI. Tujuan dari kegiatan penyuluhan ini adalah untuk memberikan kesadaran dari pelaku UMKM mengenai pentingnya aspek legalitas usaha termasuk didalamnya prosedur pengurusan beserta manfaat dari adanya legalitas usaha. Target peserta sebanyak 30 pelaku UMKM dimaksudkan untuk memberikan dampak yang lebih luas, tidak hanya kepada kedua mitra. Kegiatan ini juga melibatkan Dinas Perindustrian, Koperasi dan UMKM Kabupaten Tuban sebagai salah satustakeholder pengembangan UMKM.

2. Perancangan Alat Produksi : Alat produksi yang direncanakan dikembangkan pada program ini adalah mesin pemotong (cutter machine) dan mesin press otomatis. Proses perancangan alat dilakukan melibatkan Laboratorium Teknik Industri dan UMKM yang memproduksi peralatan dan permesinan.

3. Pengurusan Ijin usaha dan Pendaftaran Merk : Pengurusan ijin usaha melalui Kantor Dinas Perindustrian, Koperasi dan UMKM Kabupaten Tuban. Pada tahap ini, pengusul akan melakukan pendampingan dan pembiayaan kepada kedua mitra dalam menyiapkan dokumen yang diperlukan. Sedangkan untuk pendaftaran merek mengacu pada prosedur yang telah ditetapkan.

4. Perancangan E-Commerce : Pada tahap ini, pengusul akan menyiapkan sebuah laman dengan menggunakan CMS (Content Management System) yang sederhana sehingga mudah dipahami oleh kedua mitra.

\section{HASIL PEMBAHASAN}

Langkah awal yang dilaksanakan oleh tim adalah pertemuan awal dengan mitra untuk sosialisasi program dan menyepakati jadwal tentatif program. Sosialisasi yang dimaksud adalah memaparkan program yang akan dilaksanakan selama tahun berjalan. Proses ini penting dikarenakan kedua mitra perlu memahami maksud dan tujuan program yang akan dilaksanakan. Terlebih pula, terdapat rentang waktu selama satu tahun antara pengusulan proposal dengan pelaksanaan, sehingga seringkali dijumpai mitra tidak memahami atau sudah lupa konsep awal program yang dahulu telah dibahas bersama.

Pada pertemuan ini disepakati jadwal tentatif program, termasuk pemilihan waktu pelaksanaan kegiatan sosialisasi HKI dan pelatihan pemasaran. Selain itu, pada kegiatan ini juga disepakati konsep desain etiket merek dari kedua mitra yang nantinyaakan didaftarkan ke Direktorat Hak Kekayaan Intelektual, Kementerian Hukum dan Hak Asasi Manusia.

Tabel 1. Capaian Hasil

\begin{tabular}{|c|c|c|}
\hline Indikator & Sebelum & Sesudah \\
\hline $\begin{array}{l}\text { Legalitas } \\
\text { Usaha }\end{array}$ & $\begin{array}{l}\text { Belum } \\
\text { memiliki } \\
\text { ijin usaha }\end{array}$ & $\begin{array}{l}\text { Sudah memiliki ijin } \\
\text { usaha : } \\
\text { - Surat Ijin Usaha } \\
\text { Perdagangan (SIUP) } \\
\text { - Tanda Daftar } \\
\text { Perusahaan (TDP) } \\
\text { - Surat Ijin Tempat } \\
\text { Usaha (SITU) } \\
\text { - NPWP (Nomor } \\
\text { Pokok Wajib Pajak) }\end{array}$ \\
\hline $\begin{array}{l}\text { Alat } \\
\text { Produksi }\end{array}$ & $\begin{array}{l}\text { Mesin pres } \\
\text { manual, } \\
\text { mesin } \\
\text { potong } \\
\text { manual }\end{array}$ & $\begin{array}{l}\text { - Desain dan } \\
\text { pembuatan alat } \\
\text { pemotong } \\
\text { - Desain dan } \\
\text { pembuatan alat pres }\end{array}$ \\
\hline $\begin{array}{l}\text { Etiket } \\
\text { Merk }\end{array}$ & $\begin{array}{l}\text { Belum } \\
\text { memiliki } \\
\text { etiket } \\
\text { merek }\end{array}$ & $\begin{array}{l}\text { Telah dirancang desain } \\
\text { etiket } \\
\text { merek }\end{array}$ \\
\hline $\begin{array}{l}\text { Merek } \\
\text { terdaftar }\end{array}$ & $\begin{array}{l}\text { Belum } \\
\text { memiliki } \\
\text { merek } \\
\text { terdaftar }\end{array}$ & $\begin{array}{l}\text { Telah diproses } \\
\text { pendaftaran merek } \\
\text { melalu Sentra HKI } \\
\text { UTM }\end{array}$ \\
\hline $\begin{array}{l}\text { Pemasaran } \\
\text { On-Line }\end{array}$ & $\begin{array}{l}\text { Belum } \\
\text { tersedia } \\
\text { sarana } \\
\text { pemasaran } \\
\text { online }\end{array}$ & $\begin{array}{l}\text { Telah dirancang toko } \\
\text { online di } \\
\text { laman } \\
\text { http://sandalwisata.com }\end{array}$ \\
\hline
\end{tabular}

\section{Legalisasi Usaha}

Legalisasi usaha dilakukan dengan mengurus perijinan, seperti Tanda Daftar Perusahaan (TDP) dan SIUP (Surat Ijin Usaha Perdagangan). Proses pendaftaran dilakukan melalui kantor Badan Pelayanan Perijinan Terpadu Pemerintah KabupatenTuban. 
Tabel 1. Legalitas Usaha Mitra

\begin{tabular}{|c|c|c|c|}
\hline No & UKM & Aspek Perijinan & Nomor/Tanggal \\
\hline \multirow[t]{3}{*}{1} & Bintang Lima & Surat Ijin Tempat Usaha (SITU) & $\begin{array}{l}\text { 503/2835/414.213/2015 } \\
\text { Tertanggal1 Juli } 2015 \\
\text { dikeluarkan oleh } \\
\text { Kec Semanding, Kab Tuban }\end{array}$ \\
\hline & & $\begin{array}{l}\text { Surat Ijin Usaha } \\
\text { Perdagangan (SIUP) }\end{array}$ & $\begin{array}{l}\text { 514.1/675.SIUP.B- } \\
\text { K/414.114/2015 } \\
\text { Tertanggal 13 Juli } 2015 \\
\text { dikeluarkan oleh } \\
\text { Badan Pelayanan Perijinan } \\
\text { Terpadu Pemkab Tuban. }\end{array}$ \\
\hline & & $\begin{array}{l}\text { Tanda Daftar Perusahaan } \\
\text { (TDP) }\end{array}$ & $\begin{array}{l}\text { 517.2/686/TDP-Po/414.114/2015 } \\
\text { Tertanggal 13 Juli } 2015 \\
\text { dikeluarkan oleh } \\
\text { Badan Pelayanan Perijinan } \\
\text { Terpadu Pemkab Tuban. }\end{array}$ \\
\hline \multirow[t]{3}{*}{2} & Tasmania & Surat Ijin Tempat Usaha (SITU) & $\begin{array}{l}\text { 503/1564/414.214/2015 } \\
\text { Tertanggal } 11 \text { Nipember } 2015 \\
\text { dikeluarkan oleh Kec Tuban Kab } \\
\text { Tuban }\end{array}$ \\
\hline & & $\begin{array}{l}\text { Surat Ijin Usaha } \\
\text { Perdagangan (SIUP) }\end{array}$ & $\begin{array}{l}\text { 517.1/1050.SIUP.B- } \\
\text { K/414.114/2015 } \\
\text { Tertanggal } 17 \text { Nopember } 2015 \\
\text { dikeluarkan oleh Badan } \\
\text { Pelayanan } \\
\text { Perijinan Terpadu Pemkab } \\
\text { Tuban. }\end{array}$ \\
\hline & & $\begin{array}{l}\text { Tanda Daftar Perusahaan } \\
\text { (TDP) }\end{array}$ & $\begin{array}{l}\text { 517.2/1066/TDP- } \\
\text { Po/414.114/2015 } \\
\text { Tertanggal } 17 \text { Nopember } 2015 \\
\text { dikeluarkan oleh Badan } \\
\text { Pelayanan } \\
\text { Perijinan Terpadu Pemkab } \\
\text { Tuban. }\end{array}$ \\
\hline
\end{tabular}

\section{Desain Etiket Merek}

Istilah Etiket Merek atau Trademark Etiquette berarti label atau tag. Etiket Merek adalah contoh merek dalam permohonan pendaftaran merek yang diajukan kepada Direktorat Jenderal Hak Kekayaan Intelektual (Ditjen HKI). Pada proses permohonan pendaftaran merek disyaratkan melampirkan etiket merek yang dicetak di atas kertas. Walau banyak ditemui permohonan pendaftaran merek yang menerakan etiket merek dalam bentuk huruf standar dalam warna hitam dan putih saja. Etiket merekdalam permohonan pendaftaran merek sebaiknya mencakup semua jenis warna dan elemen merek sesuai pemakaian. Merek harus merepresentasikan atau mewakili merek sesuai yang dilekatkan pada barang atau jasa yang diproduksi dan diperdagangkan, atau sebagaimana konsumen menjumpainya dalam perdagangan barang/jasa.
Apabila permohonan dikabulkan Ditjen HKI, maka perlindungan hukum diberikan kepada merek sebagaimana ditampilkan dalam permohonannya. Penghapusan pendaftaran Merek dari Daftar Umum Merek dapat dilakukan atas prakarsa Ditjen HKI atau pihak ketiga melalui gugatan ke Pengadilan Niaga berdasarkan kondisi non-use karena pemakaian merek dalam aktivitas komersial tidak sesuai dengan merek yang didaftarkan. Proses pembuatan desain etiket merek didasarkan pada masukan dari kedua mitra, antara lain desain dan warna yang sederhana sehingga dapat dengan mudah diaplikasikan pada sandal baik dengan sablon maupun emboss. 


\section{Pendaftaran Merek}

Pendaftaran merek dilakukan melalui Sentra HKI UTM. Kedua merek didaftarkan atas nama masing-masing pemilik UKM. Pada awalnya merek didaftarkan hanya untuk satu jenis barang pada kelas 25, yaitu sandal. Namun berdasarkan diskusi dengan pihak Sentra HKI UTM, tim mengusulkan pendaftaran merek untuk sepatu dan kaos. Hal ini dikarenakan satu merek dapat didaftarkan untuk 10 jenis barang. Tim juga melihat potensi perkembangan usaha dari kedua mitra yang sangat memungkinkan untuk memproduksi barang lain yang masih termasuk dalam kelas 25 .

\section{Pembuatan Fasilitas Toko On-Line}

Era digital menuntut kreatifitas pemasaran untuk menjangkau pasar yang lebih luas. Salah satu upaya yang perlu dilakukan adalah dengan mengembangkan took online. Oleh karena itu, kedua mitra perlu dikenalkan dengan konsep pemasaran online. Langkah yang diambil adalah dengan merancang toko online dengan laman $\mathrm{http} / / /$ sandalwisata.com. Selain penyiapan laman toko online, perlu pula dilakukan pelatihan sehingga kedua mitra siap untuk memasarkan produknya dengan menggunakan aplikasi toko online tersebut.

\section{KESIMPULAN}

Kesadaran mitra terhadap HKI, khususnya merek masih rendah. Ini disebabkan selama ini mitra merasa tidak membutuhkan merek. Namun demikian, perlu diantisipasi perkembangan bisnis ke depan. Merek untuk kedua mitra telah diproses pendaftarannya melalui Sentra HKI UTM. Perancangan alat ditujukan untuk meningkatkan kapasitas produksi mengingat, kedua mitra telah mendapatkan kepercayaan dari pasar. Pengembangan pemasaran melalui media toko online diharapkan mampu memperluas cakupan pasar. Aplikasi etiket merek perlu mulai dilakukan secara bertahap, mulai dari pencantuman di nota, kwitansi, papan nama, stempel, laman e-commerce dan beberapa identitas lainnya. Target akhir adalah pencantuman pada sandal. Merek yang didaftarkan dapat dipergunakan untuk produk sandal, sepatu dan kaos. Peluang usaha untuk memproduksi barang ini perlu untuk dipikirkan oleh kedua mitra.

\section{DAFTAR PUSTAKA}

Badan Pusat Statistik. 2015. Kinerja Ekonomi Kreatif Indonesia. Makalah Simposium Nasional Kementerian Pariwisata dan Ekonomi Kreatif.

Molla, A. Heeks, R. 2007. Exploring ECommerce Benefits for Businesses in a Developing Country. The Information Society. 23: 95-108. 